\title{
Dante's Drunkenness and Virgil's Rebuke (Purg. 15.115-138)
}

\section{Lauren Scancarelli Seem}

There has been a growing awareness in recent studies on the Commedia of the need to re-assess Virgil's role in Dante's poem. We are coming to recognize the complex strategy that underlies Dante's treatment of the classical poet: while the pilgrim may honor his guide as "lo mio maestro e 'I mio autore," the poet gradually dismantles Virgil's authority. To give but a few examples, scholars have pointed out how Virgil is defeated before the gates of Dis, taken in by the lies of the Malebranche in the circle of the barrators, and rebuked by Cato on the shores of Purgatory. ${ }^{1}$ The present study seeks to extend this critical re-examination of Virgil's status to Purgatorio 15, to the exchange between pilgrim and guide which closes the canto.

Purgatorio 15 finds Dante and Virgil newly arrived on the mountain's third terrace. The pattern set on the lower terraces continues, and the pilgrim is first exposed to examples of gentleness in order to prepare him for witnessing the purgation of anger. The exempla take the form of three ecstatic visions which hold Dante in a Pauline-like rapture ("Ivi mi parve in una visione / estatica di sùbito esser tratto" Purg. $15.85-6){ }^{2}$ In the first vision Mary mildly scolds her son when she finds him in the temple discoursing with the teachers. The second is of Pisistratus's clemency toward the youth who kissed his daughter publicly, and the third portrays the stoning of St. Stephen and the protomartyr's gentleness in praying for his persecutor's forgiveness. Dante wakes from these visioni to an admonishing question from his guide:

"Che hai che non ti puoi tenere, ma se' venuto più che mezza lega velando li occhi e con le gambe avvolte, a guisa di cui vino o sonno piega?"

(Purg. 15.120-3)

Dante assumes that Virgil questions his behavior because he does not realize what has happened and begins to relate his visionary experience to his guide:

"O dolce padre mio, se tu m'ascolte, io ti dirò," diss'io, "ciò che m'apparve quando le gambe mi furon sì tolte."

(Purg. 15.124-6) 
But the "kind father" will not listen. Cutting short Dante's explanation, Virgil insists that he already knows what Dante has just experienced. The point of his question, Virgil explains, was to hurry Dante's lagging steps as he awoke from his visions:

Ed ei: "Se tu avessi cento larve sovra la faccia, non mi sarian chiuse le tue cogitazion, quantunque parve.

Ciò che vedesti fu perché non scuse d'aprir lo core a l'acque de la pace che da l'etterno fonte son diffuse.

Non dimandai 'Che hai?' per quel che face chi guarda pur con l'occhio che non vede, quando disanimato il corpo giace; ma dimandai per darti forza al piede: così frugar conviensi i pigri, lenti ad usar lor vigilia quando riede."

(Purg. 15.127-138)

I believe that this exchange between pilgrim and guide requires closer examination. When Virgil first questions his charge, does he realize why Dante is exhibiting such strange behavior? I would like to examine the possibility (hitherto unbroached, as far as I have been able to ascertain) that the pilgrim's initial assumption, that Virgil asks "che hai?" because he does not understand the nature of Dante's visionary condition, might be correct after all. If this is true, then Virgil, rather than be thought ignorant, insists upon a knowledge he did not possess. What is at issue here is more than a question of Virgil's veracity in one discrete episode, but that of the Commedia's treatment of the limitations of a pagan guide in a Christian place.

The problem with Virgil's part in the exchange begins with the very first words he speaks - "che hai." The difficulty lies in reconciling Virgil's language with his professed purpose. If the rebuke were indeed intended to hasten the pilgrim on his way ("per darti forza al piede," as Virgil will assert some thirteen lines later), the colloquial, even rude exordium seems inappropriate, the comparison of Dante to a drunkard gratuitously insulting. If, however, Virgil were to see his charge stumbling along the terrace without observing any reason for this extraordinary behavior, a sharp rebuke would be an appropriate response. Yet Virgil is anxious to deny that this more natural scenario took place, insisting instead that he was perfectly aware of Dante's vision-induced condition.

The antagonism in Virgil's question has not gone without some notice in the commentary tradition. Francesco Torraca, while he assures the reader that the misunderstanding is Dante's and not Virgil's, does remark that "il tono di tutta la domanda è piuttosto aspro" (447). Manfredi Porena comments at length on the three-line question:

[the episode] presenta un Virgilio che si mostra alquanto inesplicabilmente severo 
verso Dante, e si direbbe metta un gusto speciale a punzecchiare il suo alunno, paragonandolo a un sonnacchioso o a un ubbriaco pel suo strano modo di camminare ... Insomma Virgilio usa qui di un ingiustificata severità verso il discepolo. (244$5)^{3}$

While the perceived antagonism in Virgil's question might possibly be a case of unfortunate phrasing obscuring kindly intentions, less easily dismissed are the figural associations that the three-line rebuke contains. When Virgil provides a description of the pilgrim stumbling along the terrace, his eyes veiled as though asleep, the guide seems unaware that he is establishing a figural relationship between Dante and St. John. The author of the Apocalypse is traditionally depicted in medieval art with his eyes closed in visionary sleep as he receives revelation on the island of Patmos. Dante himself makes use of this iconographic representation in Purgatorio 29 where St. John brings up the rear in the procession of the books of the Bible. There he is not directly named, but identified instead by his visionary sleep:

e di retro da tutti un vecchio solo

venir, dormendo, con la faccia arguta.

(Purg. 29.143-4)

Like sleepwalking, the charge of drunkenness also has typological significance. Three subtexts combine to provide Dante's apparently drunken behavior with an honorific history. The first is from the book of Jeremiah where, inspired by God, Jeremiah delivers a polemic against the false prophets who are deceiving the faithful. He begins his speech by describing his physical state as the word of God descends upon him:
contritum est cor meum in medio mei contremuerunt omnia ossa mea, factus sum quasi vir ebrius et quasi homo madidus a vino a facie Domini et a facie verborum sanctorum eius.

(Jeremiah 23:9)

While Virgil's rebuke establishes a flattering parallel between Dante's experience and that of the Hebrew prophet, the Biblical subtext also resolves a problem that lies behind all mystical experiences, Dante's included: how can genuine experiences be distinguished from fraudulent ones? The association with Jeremiah reaffirms Dante's claim that his visioni were "non falsi errori" (Purg. 15.117). Dante, like Jeremiah, is a true prophet. ${ }^{5}$

This Old Testament typology of prophetic vision as drunkenness continues in the New Testament. The poet has already drawn upon the book of Acts earlier in the canto for the stoning of St. Stephen, ${ }^{6}$ and now Virgil's charge of drunkenness directs the reader there again. Acts 2:1-13 recounts that on Pentecost the Apostles were visited by the Holy Spirit and received the gift 
of tongues. As the Apostles left the temple, a crowd gathered to hear their strange speech:

stupebant autem omnes et mirabantur

ad invicem dicentes

quidam hoc vult esse

alii autem inridentes dicebant

quia musto pleni sunt isti.

(Act 2:12-3) ${ }^{7}$

Virgil's admonishing question affects an interesting comparison. If Dante in his reaction to the visioni is like the inspired apostles, then Virgil, by rebuking Dante, unwittingly casts himself as one of the scoffers in the crowd.

I would further like to suggest that these two Scriptural subtexts valorizing Dante's seemingly drunken behavior are joined by a third text, Dante's own Vita Nuova. In Vita Nuova 3 Beatrice favors Dante with her saluto for the first time and the poet records his reaction in his 'libro de la memoria':

come inebriato mi partio de le genti, e ricorsi a lo solingo luogo d'una mia camera, e puosimi a pensare di questa cortesissima. E pensando di lei, mi sopragiunse uno soave sonno, ne lo quale m'apparve una maravigliosa visione.

The episodes in Vita Nuova 3 and Purgatorio 15 contain some suggestive parallels. Vita Nuova 3.1 marks Dante's second "sighting" of Beatrice. ${ }^{8}$ Before Beatrice appears in Purg. 30 to discharge Virgil from his duty, Virgil mentions her by name three times during the climb, the second time at Purg. 15.77. ${ }^{9}$ After he receives Beatrice's greeting in the Vita Nuova, Dante experiences a drunken sensation; he is "come inebriato." He then falls into a sleep in which he has a "maravigliosa visione." Almost directly upon hearing Beatrice's name in Purg. 15.77 Dante is rapt in a "visione / estatica."10

The subtextual presence of the Vita Nuova at this juncture in the Commedia mutually vindicates Dante's past and present behavior. By staggering drunkenly along Purgatory's third terrace, Dante rejects the possibility that his youthful reaction at the sight of Beatrice was nothing more than the usual manifestation of an Ovidian lovesickness. Instead, what the Vita Nuova recorded was the experience of a man receiving a sacred vision. Despite whatever reaction it might prompt from his guide, Dante, whether a youth of 18 or a man of 35 , intuitively reacts correctly when he receives such a vision - he acts the way Jeremiah and the Apostles did, as though he were drunk.

This idea of drunkenness and sleep as the proper reactions to Christian experience will later be reinforced in two episodes in the Paradiso. In $\mathrm{Pa}$ radiso 27 Dante, who has just successfully completed his examination on the three theological virtues, is rewarded by a singing of the Gloria Patri. The poet describes his joy as inebriation:

'Al Padre, al Figlio, a lo Spirito Santo' 
cominciò, 'gloria!' tutto 'l paradiso, sì che $\mathrm{m}$ 'inebriava il dolce canto.

Ciò ch'io vedeva mi sembiava un riso de l'universo; per che mia ebbrezza intrava per l'udire e per lo viso.

(Par. 27.1-6)

Then in Paradiso 32 St. Bernard ends his account of the saints seated in the rose:

Ma perché 'l tempo fugge che t'assonna, qui farem punto, come buon sartore che com'elli ha del panno fa la gonna;

(Par. 32.139-141)

Looking at the saved souls Dante sleeps the visionary sleep of St. John.

Yet despite the honorific parallels that can be drawn from Virgil's rebuke, Dante is understandably eager to absolve himself in his master's eyes:

"O dolce padre mio, se tu m'ascolte io ti dirò," diss'io, "ciò che m'apparve quando le gambe mi furon sì tolte."

(Purg. 15.124-6)

At Dante's offer of an explanation of what has just transpired Virgil becomes even more anxious to exonerate himself from the suspicion of ignorance than Dante was to clear himself from a charge of drunken behavior. Virgil produces four "proofs" in as many tercets that he was completely cognizant of Dante's visionary experience when he asked the admonishing question.

In the first tercet Virgil claims that he can read Dante's thoughts:

"Se tu avessi cento larve

sovra la faccia, non mi sarian chiuse

le tue cogitazion, quantunque parve."

(Purg. 15.127-9)

Several commentators suggest that the reader compare this boast to a similar one made in Inf. 23.25-27. ${ }^{11}$ The comparison is a telling one. Inferno 23 finds Dante and Virgil in the fifth bolgia of the circle of fraud. As they try to find the bridge leading into the next bolgia, Dante is seized with the fear that the Malebranche, earlier just barely kept at bay, might now be about to swoop down upon them. He relates his fear to his guide who responds with an elaborate boast of his ability to read Dante's mind:

" $S$ 'i' fossi di piombato vetro,

l'imagine di fuor tua non trarrei

più tosto a me, che quella dentro 'mpetro."

(Inf. 23.25-7) 
Skeptical of Virgil's claim, Mark Musa remarks,

this is surely a case where simple common sense could enable one of the two people in danger to imagine his companion's thoughts. Virgil's elaborate praise of his own clairvoyance must make the reader smile. (150-1)

Musa's comment alerts the reader that Virgil's claim should be treated with suspicion, but it does not remark on what I find to be the primary flaw in Virgil's behavior - his choice of poesis over praxis. Virgil responds to Dante's call for immediate action ("se non celi / te e me tostamente . . ." Inf. 23.212) with a speech that is so long that in fact Virgil is still talking ("Già non compié di tal consiglio rendere" Inf. 23.34) when the Malebranche appear on the scene to carry Dante off. Virgil effects a hasty escape, grabbing Dante in his arms and sliding into the next ditch. Although this dramatic rescue generates the tender simile in which Virgil is compared to a mother carrying her child to safety from a burning house (Inf. 23.37-42), it does not alter the fact that Virgil, with his protracted speech, exposed his charge to further danger. In addition, Virgil's failure to comprehend the nature of the situation in the first place is especially glaring since, by his own admission (Inf. 21.623), Virgil has tangled with the Malebranche before and knows what slippery devils they are. The episode in Inferno 23 establishes a troubling precedent which should put the reader on his guard when in Purgatorio 15 Virgil makes a similar claim for his own powers of divination. ${ }^{12}$

After making this claim, Virgil explains the purpose for the vision of gentleness in the second tercet:

"Ciò che vedesti fu perché non scuse

d'aprir lo core all'acque de la pace

che da l'etterno son diffuse."

(Purg. 15.130-3)

These lines provide the most convincing evidence that Virgil was indeed privy to Dante's experience, for how could he possibly be able to explicate the visioni if he does not understand what has occurred? Torraca apparently follows this line of reasoning and comments that this tercet "è la prova che Virgilio non solo sa ciò che a Dante è capitato ma ne sa anche la ragione" (447).

But does Virgil ever actually demonstrate the knowledge with which Torraca credits him - that he knows both what happened and why? Dante has just offered to tell his guide what he has seen ("ciò che m'apparve" Purg. 15.125). Virgil, responding to Dante's offer of information, refers to the visioni only as "ciò che vedesti" (Purg. 15.130). As far as the content of the visions is concerned Virgil volunteers nothing that the pilgrim has not already supplied. If Virgil does indeed have a more precise knowledge of what has transpired, he never actually demonstrates it. Furthermore Virgil's explanation of the reason for Dante's experience (Torraca's "anche la ragione") is also suspiciously vague. To explain that the incident was meant to teach the pilgrim 
to open his heart to the waters of peace is really to do no more than reiterate the general function of the exempla - they serve to countermand the vice. But Virgil has already explained this process on the preceding terrace (Purg. 13.37-42). In fairness to Virgil, his explication does display that he has grasped the moral order of Purgatory - he realizes that the terrace of envy is followed by the terrace of anger. ${ }^{13}$ Nevertheless, Virgil is really saying no more than that the exempla of humility on the terrace of pride serve to teach humility, the exempla of charity to teach charity, etc. This sort of explanation requires no specific knowledge of either what the exempla are or how they are presented. Any attentive reader could have done as well, except that Virgil's explanation has what Marti calls a "sapore evangelico" (77).

Virgil's use of biblical language in interpreting the visioni seems to be but one part of a larger pattern. Marti comments that,

le parole con le quali Virgilio afferma di conoscer già le ragioni, per cui Dante è venuto per mezza lega 'velando gli occhi e con le gambe avvolte' . . . salgono di un tono ed acquistano in aulicità. (77)

In support of this observation Marti cites the first tercet's three Latinisms (larve, cogitazion, and parve) as well as Virgil's apostolic tone. Marti is particularly astute in recognizing the change in Virgil's mode of speech, but he does not consider what seems to me to be the essential question here-why should Virgil suddenly upgrade his diction? The answer, I would suggest, is two-fold. First, Virgil uses a more formal and Latinate vocabulary in his second speech to achieve a conciliatory effect after the rude and colloquial language of his first speech. Second, and more speculatively, Virgil attempts to hide his lack of understanding under the ornateness of his language. Virgil's speech, in other words, functions as a smoke screen to prevent the pilgrim from realizing his guide's limitations. ${ }^{14}$

A study of the third tercet lends additional support to this suggestion. The passage is among the more obscure ones in the poem:

Non dimandai 'che hai?' per quel che face chi guarda pur con l'occhio che non vede quando disanimato il corpo giace.

(Purg. 15.133-5)

The general sense of the lines is clear. Virgil is claiming that he viewed Dante's state with understanding. The exact terms of the comparison, however, have been much disputed. The basic problem is that the phrase "quando disanimato il corpo giace" allows for two different readings, depending on whether "il corpo" is understood to refer to Virgil or Dante. If the body in question is Virgil's, the lines would translate: "I did not ask 'che hai?' for the reason which prompts one who looks only with the eye that does not see (i.e. the mortal or corporeal eye) when the body lies dead." However, if the body is Dante's, Virgil is explaining that he did not ask "like one who looks 
only with a non-comprehending eye when another's body lies in a faint." Although the second reading is now the generally accepted one, neither is really a satisfactory choice. As Bosco and Reggio remark, the former "è un concetto estremamente banale," the latter "estremamente stiracchiata" (266).

Bosco and Reggio conclude their analysis of the comparison by suggesting that "rassegnamoci anche questa volta (raramente per fortuna) a riconoscere che Dante ha usato un'espressione imprecisa" (266). But in light of what we have seen in the preceding two tercets, I wonder whether the poet is guilty of imprecise speech or if he has intentionally saddled Virgil with this convoluted simile. Regardless of the exact interpretation of the lines, Attilio Momigliano's comment seems appropriate: the passage is "trascinato" and "esprime un'idea superflua" (379). These are characteristics very much in keeping with the general nature of Virgil's speech. The comparison continues Virgil's insistence (if not over-insistence) that he understood Dante's condition. Like Virgil's boast of mind-reading, it affects an elaborate comparison; like the explication of the visioni its actual claim is vague and, like both preceding tercets, Virgil couches his remark in high-flown and excessive language.

This brings us to the final tercet of Virgil's speech. Now that Virgil has impressed upon his pupil that the reprimand was not motivated by ignorance, he at last explains just what his purpose was:

"ma dimandai per darti forza al piede;

così frugar conviensi i pigri, lenti ad usar lor vigilia quando riede."

(Purg. 15.136-8)

The reiteration here of the warning not to waste time continues a disturbing tendency that Virgil displays in Purgatorio: he seems to try to compensate for his lack of participation in the exempla by insisting on progress. Virgil's reaction is reminiscent of his behavior on the terrace of pride where the examples of humility were sculptured on the terrace wall. The first of the images, Mary at the Annunciation, riveted the pilgrim's attention and this rapture drew a mild rebuke from Virgil: "Non tener pur ad un loco la mente" (Purg. 10.46).

This earlier scene is modelled (in part) on the opening of Aeneid 6. ${ }^{15}$ Seeking the Sibyl, Aeneas comes to the temple of Apollo where he pauses to view the scenes Daedalus engraved on the temple doors. The Sibyl cuts short Aeneas' sight-seeing ("non hoc ista sibi tempus spectacula poscit," 6.37), bidding him instead to make the sacrifices necessary for his underworld journey.

Virgil's rebuke in Purgatorio 10 casts Dante as his own dallying protagonist, Aeneas, while he slips into the Sibyl's role of the stern guide. But was the pilgrim making the same mistake Aeneas made? Or more pointedly, in rebuking his charge is Virgil as justified as his own fictional guide the 
Sibyl was? The unnatural scenes depicted on the temple doors (the death of Androgeos, Pasiphae and the Minotaur, etc.) are understandably unworthy of Aeneas' prolonged stare, but is it possible to look too long at the Virgin Mary? The eternal posture of Anna described in Par. 32.134-5 ("tanto contenta di mirar sua figlia / che non move occhio per cantare osanna") would suggest that it is not. In addition, when Dante's third guide, St. Bernard, finds it necessary to give the pilgrim a similar reminder not to look only at one place, he is prompting Dante not to look away from Mary, but to gaze at her. ${ }^{16}$

Virgil's insistence on progress instead of response on the terrace of pride is demonstrated again a few lines later. As the pair pass the last of the images of humility (Trajan acknowledging a widow's claim for justice), Dante delights:

di guardare

l'imagini di tante umilitadi,

e per lo fabbro loro a veder care.

(Purg. 10.97-9)

But Virgil calls Dante's attention away from the wall so that they may continue toward the next staircase. The teacher does not share his pupil's appreciation for God's artwork and, for a second time, Virgil cuts the aesthetic moment short.

On the terrace of anger Virgil is excluded even further from the exemplainstead of merely not appreciating them he does not even see them. Virgil's reaction to this exclusion is to insist even more strongly upon his role as guide as he sharply orders his pupil not to tarry.

This leads us back full circle to the question that began our discussion: does Virgil's 12-line justification explain the harshness of his initial rebuke? As expected, the commentators who consider the issue divide into two camps. Momigliano's voice is probably the strongest among those who judge Virgil too severely. He finds that "la lezione come altre di Virgilio sembra piuttosto appiccicata" (379). ${ }^{17}$ This evaluation of Virgil's behavior has been sharply criticized by both Sapegno and Bosco-Reggio.

Momigliano's "other lessons" appear in the main to refer to a similar rebuke which Dante receives in Purgatorio 5. This is probably the best place at which to pick up the debate since both Momigliano and Bosco-Reggio state their general position on Virgil's behavior in Purgatorio 5 and then ask their readers to refer to these remarks when Virgil again hurries Dante on his way in Purgatorio 15.

First let us briefly set the scene. In Purgatorio 5 Dante is leaving the lethargic when he hears the souls, already behind him, whispering because the pilgrim casts no shadow - an unprecedented occurrence. Dante turns to catch their words, and this hesitation earns him a reprimand from his guide:

"Perchè l'animo tuo tanto s'impiglia," disse 'I maestro, "che l'andare allenti? 
che ti fa ciò che quivi si pispiglia?

Vien dietro a me, e lascia dir le genti."

(Purg. 5.10-3)

Momigliano finds Virgil overly severe and comments:

Dante è attratto da quella meraviglia: di qui il rimprovero di Virgilio, sproporzionato a così lieve colpa. Virgilio appare qui un po' troppo pedagogo ... . Dopo le severe parole di Catone alle anime che si sono indugiate ad ascoltare il canto di Casella (2.118-33), Virgilio sembra un po' preoccupato di non perdere il tempo. (294)

Bosco and Reggio direct their remarks against "some critics" but the nearly word-for-word repetition of Momigliano's argument makes it quite clear that he is at least one of the major targets of their attack:

Alcuni critici hanno trovato il tono di questo rimprovero sproporzionato all'occasione che lo determina, ma esso va spiegato e giustificato col sostrato didascalico di Virgilio, guida e maestro del poeta. Più che nell'Inferno, qui nel Purgatorio ogni deviazione, ogni certezza, assume una speciale gravità. Nel secondo regno Dante non è più soltanto lo sgomento spettatore dei terribili effetti del peccato come nell'Inferno ma compie egli stesso un'espiazione, per cui ogni indugio al fine della propria purificazione diventa colpa. $(82)^{18}$

The Bosco and Reggio argument has a good deal on its side. Momigliano appears to ignore the time constraint placed on Dante's journey. By Wednesday morning, Virgil must bring his charge to the Earthly Paradise, and this fact should be considered whenever Virgil hastens Dante along-every moment is indeed precious. Furthermore, Belacqua and the other indolent souls confined to lower Purgatory have shown the very real spiritual danger of delay. However, while Bosco and Reggio are quite correct in emphasizing Dante's change of status from spectator in Hell to penitent in Purgatory, they ignore the fact that Virgil's status also undergoes a metamorphosis when he enters the second realm.

Purgatory is terra incognita to Virgil. He can no longer rely on the experience he garnered when he was sent down to the pit of Hell to do Erichtho's bidding. Beyond this geographical handicap (which displays itself in Virgil's reliance upon the penitents for directions on each terrace ${ }^{19}$ ), there is a more basic ignorance at work here; as a pagan Virgil cannot really understand Purgatory. Banned from salvation, Virgil is expected to instruct Dante in its mysteries - a task to which he proves to be unequal. Virgil's faulty comprehension of the "nuova legge" that governs the terraces was betrayed early on in the cantica when Virgil allowed Dante to listen for too long to Casella's song. ${ }^{20}$ If after Cato's rebuke Virgil is overanxious not to make the same mistake twice (as Momigliano suggests), his behavior is understandable. However, just as Virgil, despite his best intentions, did not comprehend that time spent listening to Casella's song is time wasted, in his effort to perform 
his duty diligently, he does not understand that time spent contemplating the Virgin Mary or staggering as one receives ecstatic visions is time well-spent.

\author{
Princeton University
}

\title{
NOTES
}

1 For some of the bibliography specifically concerning Virgil in the circle of the barrators and Virgil and Cato's rebuke, see notes 15 and 33 of the present study. For the problem of Virgil's role in the Commedia dealt with in a larger context see Hollander, Il Virgilio dantesco, and Barolini 201-56. I would like to thank both Robert Hollander and Teodolinda Barolini for their helpful comments on an earlier version of this essay.

2 This and all subsequent quotations from the Commedia are taken from the text established by Giorgio Petrocchi as found in the edition of Charles Singleton.

3 Porena goes on to offer a theory that accounts for the question's severity - Virgil is unusually and unjustly brusque so that Dante will have an opportunity to practice the virtue he has just witnessed in vision. On every terrace, Porena argues, Dante participates as much as possible in the condition of the souls. The pilgrim is exposed to the same exempla as those undergoing purgation, and to varying degrees he experiences their torments. Beyond this, Dante tries to incline his own soul toward the moral disposition that the terrace teaches. On the terrace of pride Porena finds Dante displaying humility when he addresses Oderisi, "Tuo vero dir m'incora / bona umilità, e gran tumor m'appiani” (Purg. 11.118-9). Similarly, on the terrace of envy Porena discerns evidence of newly acquired charity when Dante represents the souls, their eyes sewn closed, as assured of seeing the light on high. On the terrace of anger, Dante wants to demonstrate his own gentleness and Virgil's reprimand affords him the perfect occasion. The pilgrim represses whatever temptation he might feel to reply in kind, answering instead, "Dolce padre mio ....". Bosco and Reggio, however, remark that Porena's idea that Virgil is purposely severe in order to teach gentleness to his pupil "appare almeno un po' strana." See Bosco and Reggio 2.266.

4 The Vulgate is cited from Biblia Sacra.

5 For a discussion of the problem of true versus false prophets in the context of Inferno 20, see Barolini 219-20.

6 The incident is narrated in Acts 7.

$7 \mathrm{l}$ am grateful to my colleague Sheila Colwell for calling this passage to my attention.

8 The first meeting occurs in Vita Nuova 2.3 when both Dante and Beatrice are nine years old.

9 The first time Beatrice is mentioned in Purgatorio is at Purg. 6, 46, the third Purg. 18, 48.

10 There is also a suggestive, though by no means conclusive, correlation in the timing of Beatrice's appearances in the two texts. When Beatrice greets Dante in the Vita Nuova the poet informs his readers that "era fermamente nona di quello giorno" (i.e. 3 o'clock p.m.). Purgatorio 15 begins: "Quanto tra l'ultimar dell'ora terza / e 'l principio del dì par de la spera / che sempre a guisa di fanciullo scherza, / tanto pareva già inver' la sera / essere al sol del suo corso rimaso." (Purg. 15.1-5). Edward Moore comments: "The first five lines express, with a good deal of circumlocution, that 3 hours of daylight remain, in other words, it was about 3 p.m." Beatrice's name, admittedly, is not mentioned until line 77 , and some time must have elapsed during the intervening lines. Nevertheless, three o'clock in the afternoon is as close as we can come to giving the scene a temporal location.

11 Sapegno and Singleton are among the commentators who direct the reader to Inferno 23; however, they both also cite Inf. 16.118-20. But in Inferno 16 it is not Virgil but Dante who makes the claim for Virgil's powers of divination: "Ahi quanto cauti li uomini esser dienno / presso a color che non veggion pur l'ovra, / ma per entro i pensier miran col senno!" 
12 The questionable quality of Virgil's guidance in the circle of barratry has been explored in three recent studies. See Ryan 16-31, Hollander, "Virgil and Dante" 95-100, and Barolini $222-3$, and $239-40$.

13 For Virgil's knowledge of Purgatory see Purg. 17.112-139.

14 See also Barolini 207-13, for her comments on Virgil's evangelical language, and the problem of Virgil's high style in general.

15 Aeneid 1.437-93 where Aeneas views the scenes painted on the walls of the temple of Juno also provides a subtext for this episode.

16 Par. 31.112-17: “'Figliuol di grazia, quest'esser giocondo' / cominciò elli, 'non ti sarà noto / tenendo li occhi pur qua giù al fondo, / ma guarda i cerchi infino al più remoto, / tanto che veggi seder la regina / cui questo regno è suddito e devoto."'

17 Momigliano's opinion is endorsed by Marti (78).

18 For a similar argument, sec also Sapegno (46).

19 For examples of Virgil's need for directions in Purgatorio see Purg. 2.61-2, Purg. 3.52-80, and Purg. 10.100-3.

20 For a discussion of the implications of Casella's song see Hollander "Purgatorio II."

\section{WORKS CITED}

Alighieri, Dante. Vita Nuova. Ed. Domenico De Robertis. Milano: Ricciardi, 1980.

Barolini, Teodolinda. Dante's Poets. Princeton: Princeton UP, 1982.

Biblia Sacra iuxta Vulgatam Versionem. Stuttgart: Wurthenbergische Bibelanstalt, 1969.

Bosco, Umberto and Giovanni Reggio, eds. La Divina Commedia. Firenze: Le Monnier, 1979. Hollander, Robert. "Purgatorio I1: Cato's Rebuke and Dante's Scoglio." Mosaic 52 (1975).

"Virgil and Dante as Mind Readers (Inferno XXI and XXIII)." Medioevo Ro-

manzo 9 (1984).

Il Virgilio dantesco: tragedia nella "Commedia". Firenze: Olschki, 1983.

Marti, Mario. Realismo dantesco e altri saggi. Milano: Ricciardi, 1961.

Momigliano, Attilio, ed. La Divina Commedia di Dante Alighieri. Firenze: Sansoni, 1950.

Moore, Edward. The Time-References in The Divina Commedia. London, 1887.

Musa, Mark. "Virgil Reads the Pilgrim's Mind." Dante Studies 95 (1977).

Porena, Manfredi. La mia lectura Dantis. Napoli: Alfredo Guida, 1933.

Ryan, Christopher. "Inferno XXI: Virgil and Dante: A Study of Contrasts." Italica 59 (1982).

Sapegno, Natalino, ed. La Divina Commedia. Firenze: La Nuova Italia, 1968.

Singleton, Charles. The Divine Comedy of Dante Alighieri. Princeton: Princeton UP, 1970-1975.

Torraca, Francesco, ed. La Divina Commedia di Dante Alighieri. Milano: Albrighi, Segati, 1920.

Virgil. The Aeneid of Virgil. Ed. R.D. Williams. London: MacMillan, 1972. 